University of Nebraska - Lincoln

DigitalCommons@University of Nebraska - Lincoln

Hendrik J. Viljoen Publications

Chemical and Biomolecular Research Papers --

Faculty Authors Series

$9-28-2006$

\title{
Thermal analysis of the vortex tube based thermocycler for fast DNA amplification: Experimental and two-dimensional numerical results
}

\author{
V. Raghavan \\ University of Nebraska - Lincoln \\ Scott E. Whitney \\ Megabase Research Products, Lincoln, Nebraska \\ Ryan J. Ebmeier \\ Megabase Research Products, Lincoln, Nebraska \\ Nisha V. Padhye \\ Megabase Research Products, Lincoln, Nebraska \\ Michael Nelson \\ Megabase Research Products, Lincoln, Nebraska \\ See next page for additional authors
}

Follow this and additional works at: https://digitalcommons.unl.edu/cbmeviljoen

Part of the Chemical Engineering Commons

Raghavan, V.; Whitney, Scott E.; Ebmeier, Ryan J.; Padhye, Nisha V.; Nelson, Michael; Viljoen, Hendrik J.; and Gogos, George, "Thermal analysis of the vortex tube based thermocycler for fast DNA amplification: Experimental and two-dimensional numerical results" (2006). Hendrik J. Viljoen Publications. 8.

https://digitalcommons.unl.edu/cbmeviljoen/8

This Article is brought to you for free and open access by the Chemical and Biomolecular Research Papers -- Faculty Authors Series at DigitalCommons@University of Nebraska - Lincoln. It has been accepted for inclusion in Hendrik J. Viljoen Publications by an authorized administrator of DigitalCommons@University of Nebraska - Lincoln. 


\section{Authors}

V. Raghavan, Scott E. Whitney, Ryan J. Ebmeier, Nisha V. Padhye, Michael Nelson, Hendrik J. Viljoen, and George Gogos

This article is available at DigitalCommons@University of Nebraska - Lincoln: https://digitalcommons.unl.edu/ cbmeviljoen/8 


\title{
Thermal analysis of the vortex tube based thermocycler for fast DNA amplification: Experimental and two-dimensional numerical results
}

\author{
V. Raghavan \\ Department of Mechanical Engineering, University of Nebraska-Lincoln, Nebraska 68588 \\ Scott E. Whitney, Ryan J. Ebmeier, Nisha V. Padhye, and Michael Nelson \\ Megabase Research Products, 2726 North 48th Street, Lincoln, Nebraska 68504 \\ Hendrik J. Viljoen \\ Department of Chemical Engineering, University of Nebraska-Lincoln, Nebraska 68588 \\ George Gogos \\ Department of Mechanical Engineering, University of Nebraska-Lincoln, Nebraska 68588
}

(Received 8 March 2006; accepted 26 July 2006; published online 28 September 2006)

\begin{abstract}
In this article, experimental and numerical analyses to investigate the thermal control of an innovative vortex tube based polymerase chain reaction (VT-PCR) thermocycler are described. VT-PCR is capable of rapid DNA amplification and real-time optical detection. The device rapidly cycles six $20 \mu 196$ bp $\lambda$-DNA samples between the PCR stages (denaturation, annealing, and elongation) for 30 cycles in approximately $6 \mathrm{~min}$. Two-dimensional numerical simulations have been carried out using computational fluid dynamics (CFD) software FLUENT v.6.2.16. Experiments and CFD simulations have been carried out to measure/predict the temperature variation between the samples and within each sample. Heat transfer rate (primarily dictated by the temperature differences between the samples and the external air heating or cooling them) governs the temperature distribution between and within the samples. Temperature variation between and within the samples during the denaturation stage has been quite uniform (maximum variation around \pm 0.5 and $1.6^{\circ} \mathrm{C}$, respectively). During cooling, by adjusting the cold release valves in the VT-PCR during some stage of cooling, the heat transfer rate has been controlled. Improved thermal control, which increases the efficiency of the PCR process, has been obtained both experimentally and numerically by slightly decreasing the rate of cooling. Thus, almost uniform temperature distribution between and within the samples (within $1{ }^{\circ} \mathrm{C}$ ) has been attained for the annealing stage as well. It is shown that the VT-PCR is a fully functional PCR machine capable of amplifying specific DNA target sequences in less time than conventional PCR devices. (C) 2006 American Institute of Physics. [DOI: 10.1063/1.2338283]
\end{abstract}

\section{INTRODUCTION}

The polymerase chain reaction (PCR) is a powerful and sensitive enzymatic technique used to exponentially increase the number of copies of a specific sequence of template DNA. It is an important biomolecular diagnostic technique with applications in fields ranging from agriculture to biomedical research (Saiki et al., ${ }^{1}$ Kogan et al. ${ }^{2}$ Erlich, ${ }^{3}$ Saiki et al. ${ }^{4}$ Persing et al. ${ }^{5}$ Mullis et al., ${ }^{6}$ and Nicoll et al. $\left.{ }^{7}\right)$. For this reason, the PCR process has gained much attention by instrument developers and researchers working to produce a vast array of devices and operating conditions necessary to perform the reaction efficiently.

The PCR process is conducted in a series of three steps, namely, (1) sample preparation, (2) DNA amplification, and (3) product detection. The sample preparation includes DNA extraction from bacteria, viruses, blood or body fluids, etc. The DNA sample is then mixed with primers, deoxyribonucleotide triphosphates (dNTPs), magnesium, and DNA polymerase into a desirable sample volume (typically $1-100 \mu \mathrm{l}$ for amplification. During the amplification step, the sample is thermally cycled between specific denaturation, annealing, and elongation temperatures for 30-40 cycles. The typical range of denaturation temperature is $90-95^{\circ} \mathrm{C}$ and of annealing is $50-65{ }^{\circ} \mathrm{C}$. Elongation occurs around $72{ }^{\circ} \mathrm{C}\left(\right.$ Saiki $\left.^{8}\right)$. Each cycle should theoretically double the existing amount of DNA. In a practical PCR process, typical PCR amplification has an efficiency of 70\%-80\% and requires approximately 35 cycles for $10^{8}$-fold amplification.

In a typical PCR reaction, template DNA sequences lying between the ends of two specifically designed oligonucleotide primers can be amplified in approximately $30 \mathrm{~min}$ to $2 \mathrm{~h}$. This time can vary considerably according to the protocol employed and the instrument used to carry out the reaction. Gel electrophoresis is the standard for product detection. However, real-time product detection can be achieved by measuring the fluorescence of dye/DNA complexes during the amplification stage of the reaction (Higuchi et al. ${ }^{9}$ Svanvik et al., ${ }^{10}$ and Nazerenko et al. $\left.{ }^{11}\right)$. This considerably reduces the total assay time by combining amplification and product detection into a single step of the PCR process.

The automated PCR devices may generally be classified 
into two categories: robotic devices, which move the DNA samples to the heat, and thermocyclers, which bring the heat to the samples. Robotic devices are, in general, very slow; the rate of heating and cooling is approximately $2 \mathrm{~min} /$ cycle. These robotic machines also require a warming up period to bring the water baths to the correct temperatures for performing PCR. Several such devices have been reviewed by Johnson. ${ }^{12}$ The two basic types of thermocyclers are programmable heat blocks and forced hot air thermocyclers. In commonly employed heat block thermocyclers, the amplification stage consists of cycling the temperature of the samples using computer controlled heat blocks and typically requires hours of operation time. Forced hot air thermocyclers have substantially reduced typical amplification time by eliminating the large thermal mass of heat blocks and utilizing convection heat transfer between air and thin-walled capillary tubes. Therefore, the temperature transition time and the extra time needed for capillary equilibration are reduced. With these devices, PCR amplification consisting of 30 cycles can be performed in as little as $\sim 10-30 \mathrm{~min}$ (Ref. 7, Wittwer et al. ${ }^{13-16}$ ).

An improved system which uses compressed gas to increase thermocycler performance has been developed (Quintanar and Nelson, ${ }^{17}$ and Whitney ${ }^{18}$ ). These devices have higher gas velocities and a specially designed flow field to optimize heat transfer to the capillaries with DNA samples. The concept of a compressed gas thermocycler is the basis for the development of the vortex tube based polymerase chain reaction thermocycler (VT-PCR). VT-PCR is a compact thermocycler (Ebmeier et al., ${ }^{19}$ and Ebmeier $^{20}$ ).

Like with any thermocycler, there are two important performance criteria for VT-PCR. First, the most important performance criterion is the ability of VT-PCR to accurately control the temperature of the PCR samples. The VT-PCR performs thermal control by using a thermocouple placed inside an additional capillary within the sample chamber. A computer uses the feedback from the thermocouple to control the flow of hot and cold air streams. The design of the sample chamber minimizes the temperature variation between the samples. The second important performance criterion is the ability of VT-PCR to reduce the temperature variation within each sample. In this study, by using both experiments and numerical simulations, the thermal control of the VT-PCR is presented in detail. It is shown that by reducing the heat transfer rate during the annealing stage, namely, by adjusting the cold release valves in the device, the temperature variation between and within the samples during the annealing stage can be restricted to less than $1{ }^{\circ} \mathrm{C}$.

\section{EXPERIMENTAL SETUP AND PROCEDURE}

VT-PCR is an extension of its previous model, which was capable of amplifying three DNA samples. ${ }^{19}$ In the current model, there are nine capillaries placed in a modified reaction chamber. The first two capillaries are primarily used as air-flow distribution devices. A thermocouple is placed within one of the capillaries to control the process temperatures. The other six capillaries carry the DNA samples for

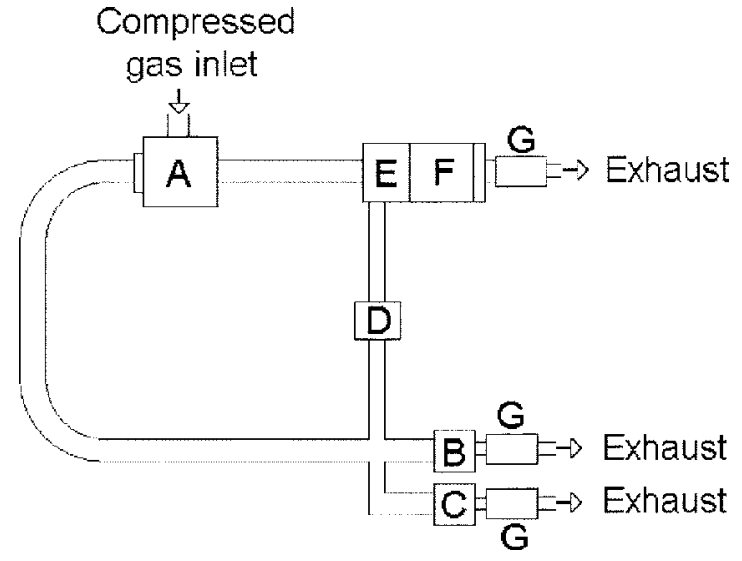

FIG. 1. Component layout of VT-PCR thermocycler. Components labeled A-G; A, Ranque-Hilsch vortex tube; B, primary cold release valve; C, secondary cold release valve; D, cold flow valve; E, mixing chamber; F, sample chamber; G, exhaust mufflers.

amplification. VT-PCR, like the previous device, relies on taking advantage of the natural heating and refrigeration capacities of the Ranque-Hilsch vortex tube (Ranque ${ }^{21}$ and $\mathrm{Hilsch}^{22}$ ). Computer control and electronically actuated flow valves are employed as necessary to use both the hot and cold exhaust streams produced from the vortex tube, to rapidly heat/cool the PCR samples. The compact design of VTPCR gives it overall dimensions of approximately $16 \times 12$ $\times 6$ in. ${ }^{3}$ In addition, it has very limited dependence on electricity $(\sim 30 \mathrm{~W})$ and can be controlled using a personal computer. In this device, 30 PCR thermal cycles between 90 and $56{ }^{\circ} \mathrm{C}$ without any holds $\left(0 \mathrm{~s}\right.$ at $90{ }^{\circ} \mathrm{C}, 0 \mathrm{~s}$ at $56^{\circ} \mathrm{C}$, and $0 \mathrm{~s}$ at $72{ }^{\circ} \mathrm{C}$ ) can be completed in less than $6 \mathrm{~min}$. The component layout of the VT-PCR is shown in Fig. 1 (more details are given in Ref. 20).

As previously mentioned, the primary difference between the current device and the previous device ${ }^{19}$ is the modified sample chamber (F, Fig. 1) to accommodate nine capillaries instead of four (current sample chamber is described in a later section). The other components remain the same as in the previous device. ${ }^{19}$ The system heats the samples by allowing only the hot air to pass through the sample chamber. The cold flow valve (D, Fig. 1) is closed, while the two cold release valves (B and C, Fig. 1) are open. This valve configuration provides two exhausts for all of the cold air produced by the vortex tube to exit the system with negligible back pressure. Meanwhile, the air exiting the hot end of the vortex tube flows across the samples located in the sample chamber before exiting the system via the sample chamber exhaust. The vortex tube is adjusted so that the hot gas temperature is approximately $105^{\circ} \mathrm{C}$ and the corresponding volumetric flow rate of hot gas produced is approximately $6.4 \times 10^{-4} \mathrm{~m}^{3} / \mathrm{s}$. The machine can heat the samples at an average rate of approximately $3.2^{\circ} \mathrm{C} / \mathrm{s}$.

The transition from heating to cooling is performed without interrupting the vortex tube operation. The cold flow valve (D, Fig. 1) is opened and then the cold release valves (B and C, Fig. 1) are closed. Adequate cooling is achieved under this configuration where the cold and hot gases mix in the mixing chamber before reaching the sample chamber. 
The mass flow rate of cold gas is about four times greater than that of the hot gas and the resulting stream is adequate to cool the samples rapidly to the annealing temperature. The cold gas exiting the vortex tube is approximately at $-5{ }^{\circ} \mathrm{C}$. The cold/hot gas mixture entering the sample chamber is typically around $25^{\circ} \mathrm{C}$. The samples are cooled at a maximum rate of about $16^{\circ} \mathrm{C} / \mathrm{s}$. By proper control of the cold release valves, intermediate cooling rates can also be obtained.

Reaction progress at the end of each cycle is monitored by measuring the fluorescence emitted at $520 \mathrm{~nm}$ by SYBR Green bound to double-stranded DNA complexes upon excitation at $470 \mathrm{~nm}$.

\section{NUMERICAL METHOD}

The fundamental equations of fluid flow and heat transfer are governed by conservation of mass, conservation of momentum, and conservation of energy. In the present study, the problem is considered transient and two dimensional. The mass, momentum, and energy transports are basically through diffusion and forced convection; the effects of radiation and natural convection are neglected. The fluid is considered to be of constant thermophysical properties. Hence, the incompressible flow solution methodology has been adopted to derive the pressure field. The transient governing equations, in terms of primitive variables can be written as follows: Continuity equation,

$$
\frac{\partial u}{\partial x}+\frac{\partial v}{\partial y}=0
$$

Momentum equation in the $x$ direction,

$$
\rho\left(\frac{\partial u}{\partial t}+u \frac{\partial u}{\partial x}+v \frac{\partial u}{\partial y}\right)=-\frac{\partial p}{\partial x}+\mu\left(\frac{\partial^{2} u}{\partial x^{2}}+\frac{\partial^{2} u}{\partial y^{2}}\right) .
$$

Momentum equation in the $y$ direction,

$$
\rho\left(\frac{\partial v}{\partial t}+u \frac{\partial v}{\partial x}+v \frac{\partial v}{\partial y}\right)=-\frac{\partial p}{\partial y}+\mu\left(\frac{\partial^{2} v}{\partial x^{2}}+\frac{\partial^{2} v}{\partial y^{2}}\right) .
$$

Energy equation,

$$
\rho C_{p}\left(\frac{\partial T}{\partial t}+u \frac{\partial T}{\partial x}+v \frac{\partial T}{\partial y}\right)=\lambda\left(\frac{\partial^{2} T}{\partial x^{2}}+\frac{\partial^{2} T}{\partial y^{2}}\right) .
$$

For pressure and velocity coupling, SIMPLE algorithm $\left(\right.$ Patankar $\left.^{23}\right)$ is used. For a guessed pressure field, $p^{*}$, the corresponding velocity field is obtained. Then, the pressure correction field $\left(p^{\prime \prime}\right)$ is obtained by solving the following pressure Poisson equation:

$$
\nabla^{2} p^{\prime \prime}=\frac{\rho}{\Delta t}\left(\frac{\partial u^{*}}{\partial x}+\frac{\partial v^{*}}{\partial y}\right)
$$

In the above equation, superscript ${ }^{*}$ implies a guessed velocity field. The pressure field for the $(n+1)^{\text {th }}$ time step is updated as $p^{n+1}=p^{*}+p^{\prime \prime}$. The corresponding velocity field is corrected in a similar fashion,

$$
u^{\prime \prime}=-\frac{\Delta t}{\rho} \frac{\partial p^{\prime \prime}}{\partial x}, \quad u^{n+1}=u^{*}+u^{\prime \prime},
$$

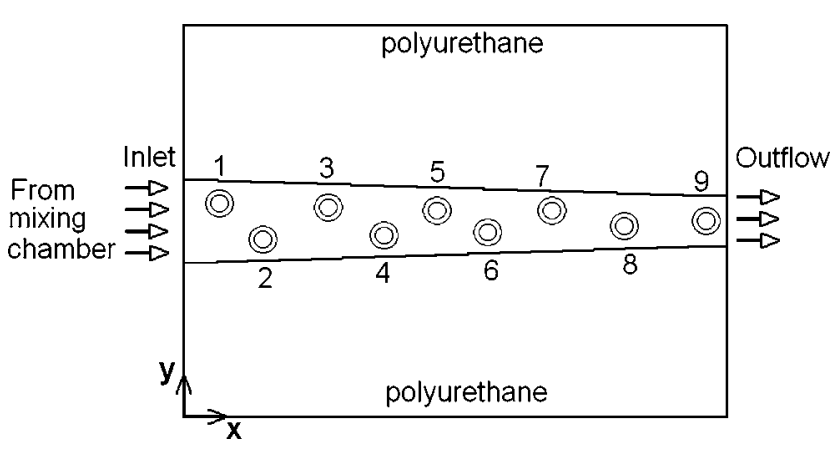

FIG. 2. Computational domain.

$$
v^{\prime \prime}=-\frac{\Delta t}{\rho} \frac{\partial p^{\prime \prime}}{\partial y}, \quad v^{n+1}=v^{*}+v^{\prime \prime} .
$$

For the hot flow simulations, the Reynolds number $(\mathrm{Re})$ based on the hot flow velocity and the average width of the sample chamber is around 1850. For the cold flow simulations, since the mass flow rate is five times higher than that of the hot flow $(\operatorname{Re}=9250)$, the flow becomes turbulent. Thus, a standard $k-\varepsilon$ model (Launder and Spalding ${ }^{24}$ ) has been employed. The equations for the standard $k-\varepsilon$ model are given below in tensor form.

Equation for turbulent kinetic energy $(k)$,

$$
\frac{\partial}{\partial t}(\rho k)+\frac{\partial}{\partial x_{i}}\left(\rho k u_{i}\right)=\frac{\partial}{\partial x_{j}}\left[\left(\mu+\frac{\mu_{t}}{\sigma_{k}}\right) \frac{\partial k}{\partial x_{j}}\right]+G_{k}-\rho \varepsilon+S_{k} \text {. }
$$

Equation for rate of dissipation $(\varepsilon)$,

$$
\begin{aligned}
\frac{\partial}{\partial t}(\rho \varepsilon)+\frac{\partial}{\partial x_{i}}\left(\rho \varepsilon u_{i}\right)= & \frac{\partial}{\partial x_{j}}\left[\left(\mu+\frac{\mu_{t}}{\sigma_{\varepsilon}}\right) \frac{\partial \varepsilon}{\partial x_{j}}\right] \\
& +C_{1 \varepsilon} \frac{\varepsilon}{k} G_{k}-C_{2 \varepsilon} \rho \frac{\varepsilon^{2}}{k}+S_{\varepsilon} .
\end{aligned}
$$

In the above equations, $G_{k}$ represents the generation of turbulence kinetic energy due to the mean velocity gradients, calculated as

$$
G_{k}=-\rho \overline{u_{i}^{\prime} u_{j}^{\prime}} \frac{\partial u_{j}}{\partial x_{i}} .
$$

The primes in the above equations represent fluctuating quantities. $S_{k}$ and $S_{\varepsilon}$ are the source terms and are equal to zero for the current problem. $\sigma_{k}$ and $\sigma_{\varepsilon}$ are turbulent Prandtl numbers and for standard $k-\varepsilon$ model they are equal to 1.0 and 1.3, respectively. $C_{1 \varepsilon}$ and $C_{2 \varepsilon}$ are constants and are equal to 1.44 and 1.92 , respectively. The turbulent or eddy viscosity $\mu_{t}$ is calculated using the equation given below:

$$
\mu_{t}=\rho C_{\mu} \frac{k^{2}}{\varepsilon}
$$

where $C_{\mu}$ in the above equation is a constant $\left(C_{\mu}=0.09\right)$.

The governing equations are solved by employing FLUENT v.6.2.16, a commercial computational fluid dynamics (CFD) tool. The transient, two-dimensional (2D), laminar, and implicit solver available in FLUENT v.6.2.16 has been employed for the hot flow simulations. For the cold flow simulations, the standard $k-\varepsilon$ model has been employed. 


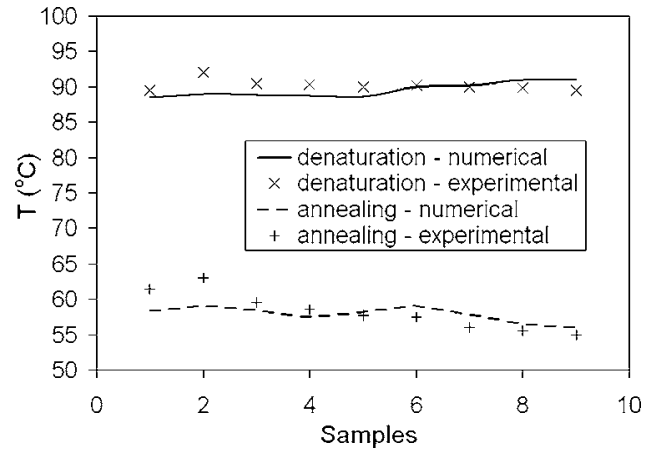

FIG. 3. Variation of temperature between all the samples during denaturation and annealing.

The computational domain shown in Fig. 2 is the sectional top view of the sample chamber (F, Fig. 1). The capillaries having an outer diameter of $1.5 \mathrm{~mm}$ and an inner diameter of $1.2 \mathrm{~mm}$ are numbered (1-9) from inlet to outflow. The top and bottom walls are made up of polyurethane and are made sufficiently thick to assume an adiabatic condition on the outer sides. Air is the working fluid in the passage outside the capillaries. Capillaries are made of glass and carry DNA samples that have thermal properties nearly equivalent to water.

At the inlet, flow velocity and appropriate temperature values, as required for the hot or cold flow simulations, are given as input $\left(u=u_{\infty}, v=0\right.$, and $\left.T=T_{\infty}\right)$. The outflow condition in the CFD software FLUENT is given for the exit (outflow) boundary so that the variables are extrapolated using the internal nodes. The outer and inner walls of the capillaries have been solved in a conjugate manner. This is carried out by employing the "coupled" condition for the inner and outer walls. The outer sides of the top and bottom walls are given an adiabatic boundary condition. Adaptive meshing based on gradients of velocity and temperature has been used to produce nonuniform, unstructured grids in the computational domain. Sufficient number of simulations has been carried out to check grid independence. Around 102500 triangular cells have been employed for all the simulations.

Capillary 7 has been chosen to control the PCR thermocycling temperatures both in the experiments and the simulations. In the experiments, the thermocouple is placed around the center of the capillary. During the heating process, the temperature at the center of capillary 7 is allowed to reach the denaturation temperature before the cooling process is activated. Similarly, the end of the cooling process is signified by the center of capillary 7 reaching the annealing temperature, when the heating process is activated again. Sufficient numbers of cycles have been simulated to completely analyze the thermal variations between the samples and within samples.

\section{RESULTS AND DISCUSSION}

\section{A. Numerical Results}

The temperatures of all the capillaries during denaturation and annealing stages of the PCR cycle $\left(0 \mathrm{~s}\right.$ at $90{ }^{\circ} \mathrm{C}$, $0 \mathrm{~s}$ at $56{ }^{\circ} \mathrm{C}$, and $0 \mathrm{~s}$ at $72{ }^{\circ} \mathrm{C}$ ), obtained both from the experiments and the numerical simulations, are shown in

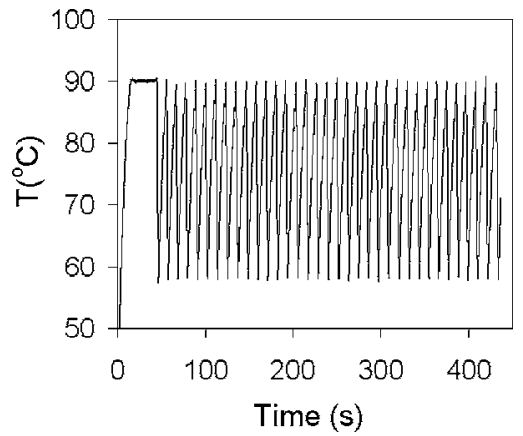

FIG. 4. Temperature vs time for the amplification of 96 bp $\lambda$-DNA.

Fig. 3. As mentioned earlier, the first two capillaries act as flow distribution devices. Capillary 7 carries a thermocouple. The other capillaries (3-6 and 8 and 9) carry the DNA samples. For more uniform performance of all the DNA samples the temperature variation between the samples should be minimized. Experimental results show that the temperature distribution between these samples, is almost uniform (within $\pm 0.5^{\circ} \mathrm{C}$ ) for the denaturation stage. The agreement between the experimental and numerical results is also good for this stage. When the machine performs with its maximum cooling rate configuration (around $16{ }^{\circ} \mathrm{C} / \mathrm{s}$ ), the difference in the temperatures between the samples during the annealing stage has been substantial (maximum variation around $3.6^{\circ} \mathrm{C}$ ). Obviously, the higher rate of cooling is the main reason for such temperature variations. Thus, by employing the intermediate cooling rate configurations by adjusting the cold release valves (presented in a later section), the temperature variation between the samples has been restricted within $1{ }^{\circ} \mathrm{C}$.

Figure 4 shows the temperature versus time profile for the protocol used to complete the PCR experiment for the amplification of $96 \mathrm{bp} \lambda$-DNA (Ref. 20). This successful PCR amplification was completed in $7 \mathrm{~min}$ and $17 \mathrm{~s}$ and required 35 cycles of $0 \mathrm{~s}$ at $90{ }^{\circ} \mathrm{C}, 0 \mathrm{~s}$ at $56{ }^{\circ} \mathrm{C}$, and $0 \mathrm{~s}$ at $72{ }^{\circ} \mathrm{C}$ preceded by a $30 \mathrm{~s}$ temperature hold at $90{ }^{\circ} \mathrm{C}$ to activate the polymerase.

In the numerical simulations, initially the samples have been at $27^{\circ} \mathrm{C}$. The hot flow simulation has been started at time $t=0 \mathrm{~s}$. After approximately $7.8 \mathrm{~s}$, the center of sample 7 reached the denaturation stage temperature $\left(90{ }^{\circ} \mathrm{C}\right)$. As mentioned earlier, the denaturation temperature varies in the

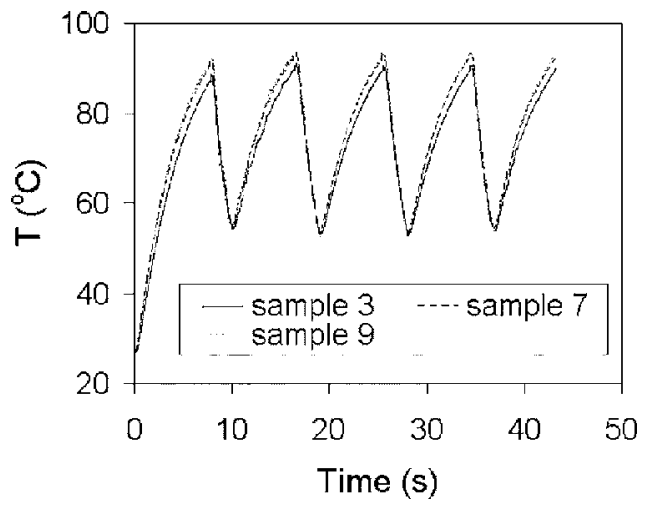

FIG. 5. Temperature vs time for samples 3, 7, and 9 . 


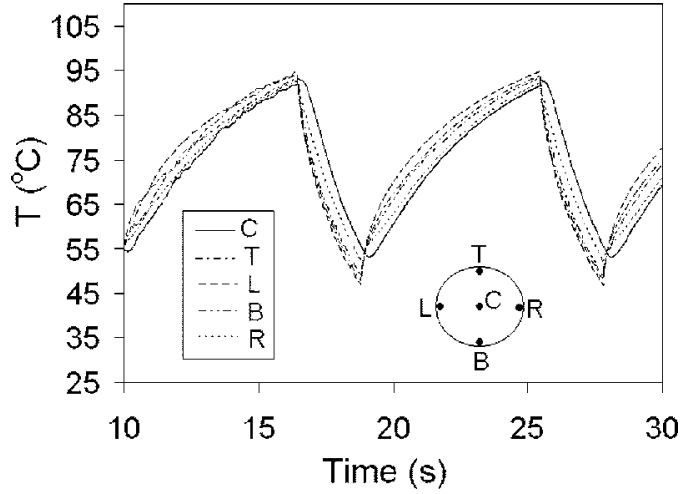

FIG. 6. Temperature vs time at five points within sample 7.

range of $90-95{ }^{\circ} \mathrm{C}$. The lowest limit of the denaturation temperature $\left(90^{\circ} \mathrm{C}\right)$ produces the largest temperature difference with respect to the heating air temperature $\left(\sim 105^{\circ} \mathrm{C}\right)$. The larger the temperature difference, the larger the heat transfer rate would be. Thus, the device's speed versus the maximum temperature variations reached between and within the samples could be thoroughly tested by studying the temperature distribution at the lowest denaturation temperature.

After the center of sample 7 reached the denaturation temperature, the cooling process is activated. The cold flow simulations, which are turbulent, have been carried out with the standard $k-\varepsilon$ model. When the maximum cooling rate configuration (around $16{ }^{\circ} \mathrm{C} / \mathrm{s}$ ) has been employed, the time taken for the center of sample 7 to reach the annealing temperature $\left(56{ }^{\circ} \mathrm{C}\right)$ from the denaturation temperature $\left(90{ }^{\circ} \mathrm{C}\right)$ has been around $2.3 \mathrm{~s}$. As soon as the center of sample 7 reached $56{ }^{\circ} \mathrm{C}$, the cold flow simulation has been stopped and again hot flow simulation has been started to repeat the next cycle. Figure 5 shows the time histories of the temperature at the centers of samples 3, 7, and 9, for about 4 cycles. The denaturation temperature of sample 3 is lower when compared to samples 7 and 9 by approximately $1.6{ }^{\circ} \mathrm{C}$ (also see the solid line in Fig. 3), which is the maximum variation between the samples. The time taken for four cycles without any hold at any stage $\left(0 \mathrm{~s}\right.$ at $90{ }^{\circ} \mathrm{C}, 0 \mathrm{~s}$ at $56{ }^{\circ} \mathrm{C}$, and $0 \mathrm{~s}$ at $72^{\circ} \mathrm{C}$ ) has been around $44 \mathrm{~s}$. The time needed to complete 35 cycles would be approximately $380 \mathrm{~s}$. If an initial hold for 30 seconds at $90{ }^{\circ} \mathrm{C}$, as in the experiment (Fig. 4), is added, then the total time required for 35 cycles would be around $410 \mathrm{~s}$ or $6 \mathrm{~min}$ and $50 \mathrm{~s}$. This compares very close to the experimental result of $7 \mathrm{~min}$ and $17 \mathrm{~s}$. The slight difference in the time can be due to the fact that numerical simulations do not include time lag when the model transitions

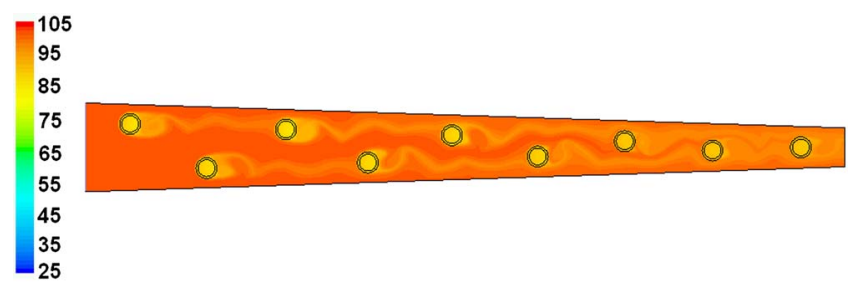

FIG. 7. (Color online) Temperature contours (in ${ }^{\circ} \mathrm{C}$ ) during denaturation stage.

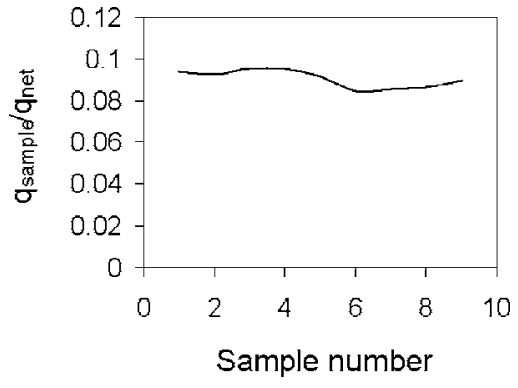

FIG. 8. Ratio of the heat transferred to the capillaries to the net heat transferred during the denaturation stage.

from hot flow to cold flow (Ref. 18), assumptions in the numerical model, and the errors in the experiments.

Figure 6 shows the time history of the temperature at five points (indicated in Fig. 9) within sample 7. It is clear from Fig. 6 that the maximum temperature difference occurs between the center point $C$ and the left point $L$. The difference in the temperature between the points $C$ and $R$ is very small. The temperature variation with time for points $T$ and $B$ are almost similar. The above trend is further explained along with the discussion for Figs. 9 and 10.

The temperature distribution in the entire domain during the denaturation stage has been shown in Fig. 7. For the hot air temperature $\left(105^{\circ} \mathrm{C}\right)$ and mass flow rate (6.4 $\times 10^{-4} \mathrm{~m}^{3} / \mathrm{s}$ ) considered, the heat flowing inside the sample chamber is around $3552 \mathrm{~J} / \mathrm{s}$. The heat flowing out of the sample chamber is around $3406 \mathrm{~J} / \mathrm{s}$ when the center of capillary 7 is at $90{ }^{\circ} \mathrm{C}$. Therefore there is a net heat transfer $\left(q_{\text {net }}\right)$ of $146 \mathrm{~J} / \mathrm{s}$ at the end of the hot flow simulation. The ratio of the heat transferred to the capillaries $\left(q_{\text {sample }}\right)$ to the net heat transferred has been plotted in Fig. 8. Each capillary receives approximately $9 \%$ of the net heat transferred from the hot flow. The remaining 19\% of the net heat has been partly transferred to the top and the bottom walls and partly stored within the domain.

Figure 9 shows the temperature contours within sample 7 at the end of the heating process. The temperatures at five points within sample 7, indicated by $C, L, R, T$, and $B$ in Fig. 9 , have been recorded. The temperature at the center point $C$ has been allowed to reach $90{ }^{\circ} \mathrm{C}$. At that instance in time, the

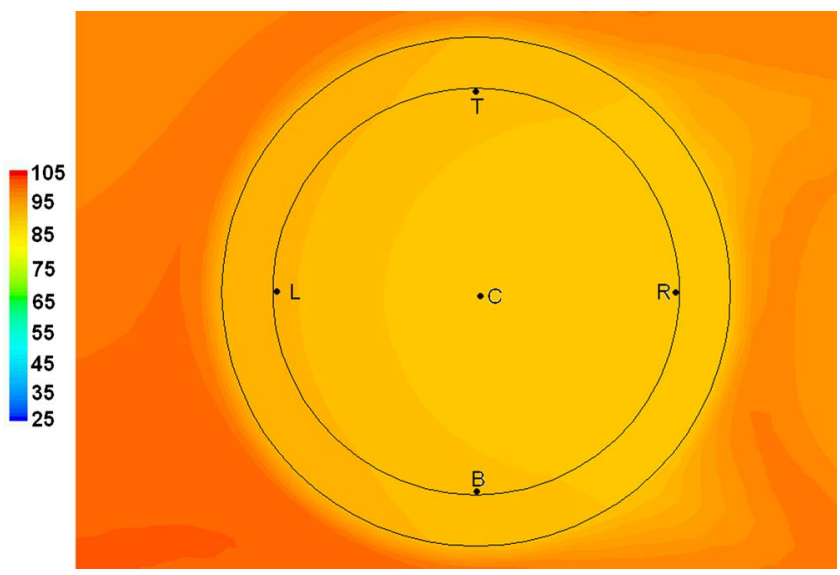

FIG. 9. (Color online) Temperature contours (in ${ }^{\circ} \mathrm{C}$ ) within sample 7 during denaturation stage. 


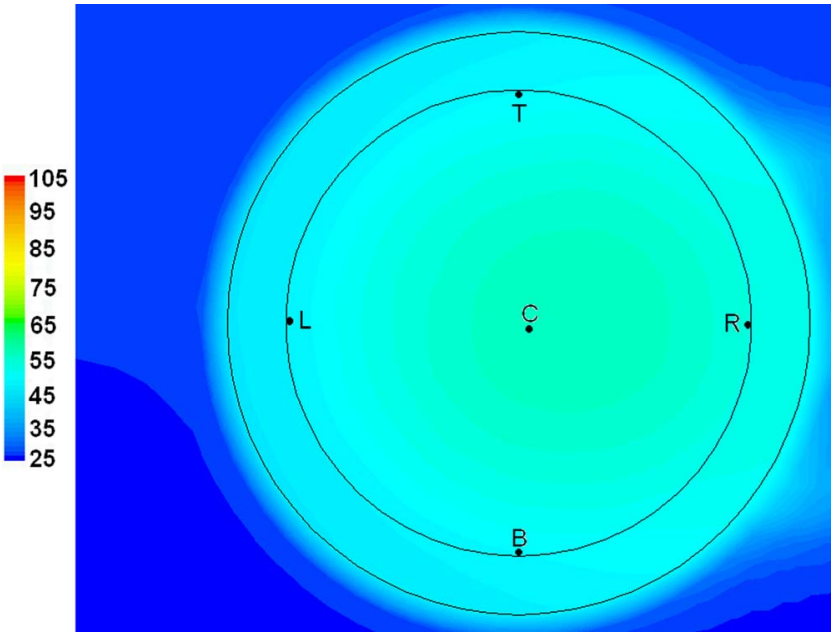

FIG. 10. (Color online) Temperature contours (in ${ }^{\circ} \mathrm{C}$ ) within sample 7 during annealing stage.

temperature variation is maximum between points $C$ and $L\left(\sim 2.8^{\circ} \mathrm{C}\right)$. That is, when the temperature at $C$ is at $90{ }^{\circ} \mathrm{C}$, the temperature at $L$ is around $92.8^{\circ} \mathrm{C}$. Similar temperature differences are reported in the literature. ${ }^{18}$ The temperature variation between $C$ and $R$ is almost negligible. At this stage, the temperature variation within the other samples has been similar to that of sample 7. Simulations conducted for a higher denaturation temperature of $95{ }^{\circ} \mathrm{C}$, which is more typical, show that the maximum temperature variation between points $C$ and $L$ is limited to $\sim 1.6{ }^{\circ} \mathrm{C}$. When temperature holds are adopted, the thermal performance improves even further, as all the capillaries attain the required equilibrium temperature during the hold period.

Figure 9 also shows that for the flow configuration considered, around $60 \%$ of the capillary cross-sectional area surrounding the center point $C$ (shown by the same color) is almost isothermal at $90{ }^{\circ} \mathrm{C}$. The higher temperature zone around point $L$ represents only around 7\% of the capillary cross section (shown by a band of darker color). If the thermocouple is placed near point $C$, larger area of the capillary cross section would be isothermal at the denaturation temperature.

Figure 10 shows the temperature contours within sample 7 during the annealing stage. With the maximum cooling rate configuration in operation, the temperature at $L$ is around $47.7^{\circ} \mathrm{C}$, when the temperature at $C$ is at $56.0^{\circ} \mathrm{C}$, producing the maximum temperature variation around $8.3{ }^{\circ} \mathrm{C}$, during this stage (similar to that reported in literature ${ }^{18}$ ). The temperature variations within the other samples are also similar

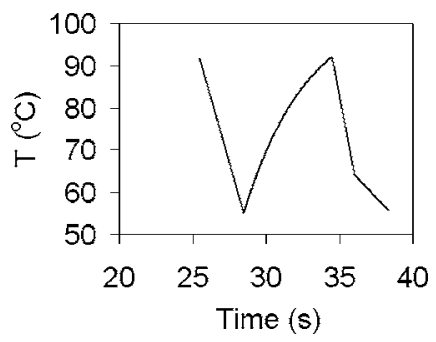

FIG. 11. Temperature vs time for sample 7, with reduced cooling rate.

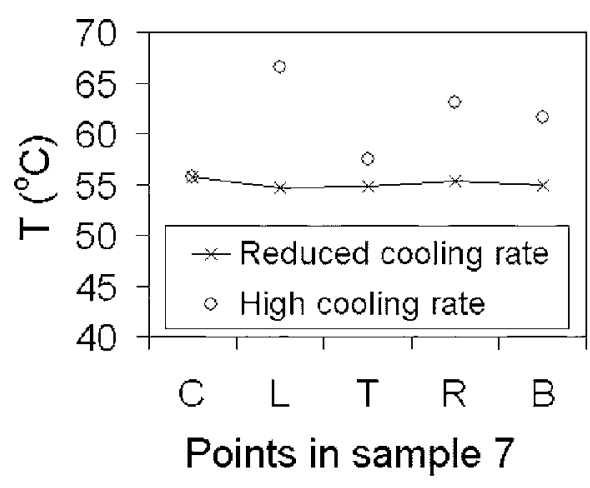

(a)

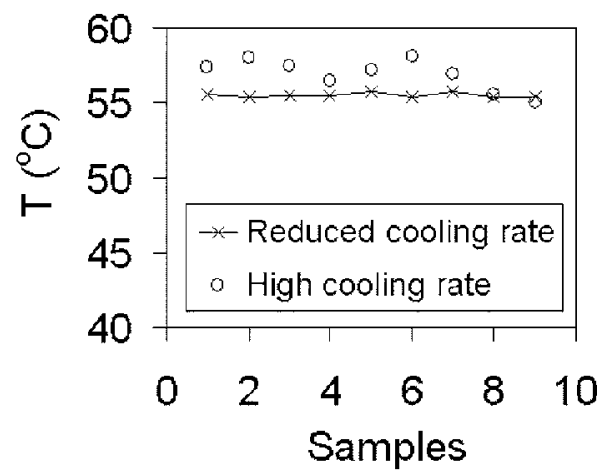

(b)

FIG. 12. Variation of temperature (a) within sample 7 and (b) between all the samples, during annealing stage with high and reduced cooling rates.

to that of sample 7. A trade-off between the device's speed and the maximum acceptable temperature variations between and within the samples can be reached by reducing the heat transfer rate during some stage of the cooling process.

As mentioned earlier, the rate of cooling is reduced in the experiments by controlling the cold flow using the cold flow valve "D" and the exhaust cold flow valves "B" and "C" (see Fig. 1). Figure 11 shows the cooling curve with the intentional decrease applied to the cooling rate after a certain time, in comparison with the normal cooling curve of the previous cycle. Employing this variable speed cooling, the maximum temperature difference within a sample has been reduced to around $1.1{ }^{\circ} \mathrm{C}$ [Fig. 12(a)]. Also, the maximum temperature difference between all the samples has been reduced to approximately $\pm 0.4{ }^{\circ} \mathrm{C}$ [Fig. 12(b)]. The results ob-

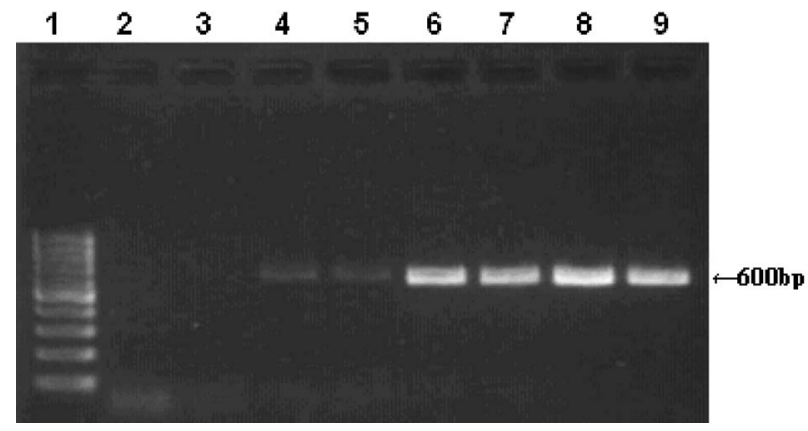

FIG. 13. Analysis of 600 bp B. cereus DNA amplicon by agarose gel electrophoresis. Lane 1: 100 bp DNA ladder; lanes 2 and 3: no DNA; lanes 4 and 5: $1 \mathrm{pg}$ DNA; lanes 6 and 7: $10 \mathrm{pg}$ DNA; lanes 8 and 9: $100 \mathrm{pg}$ DNA. 


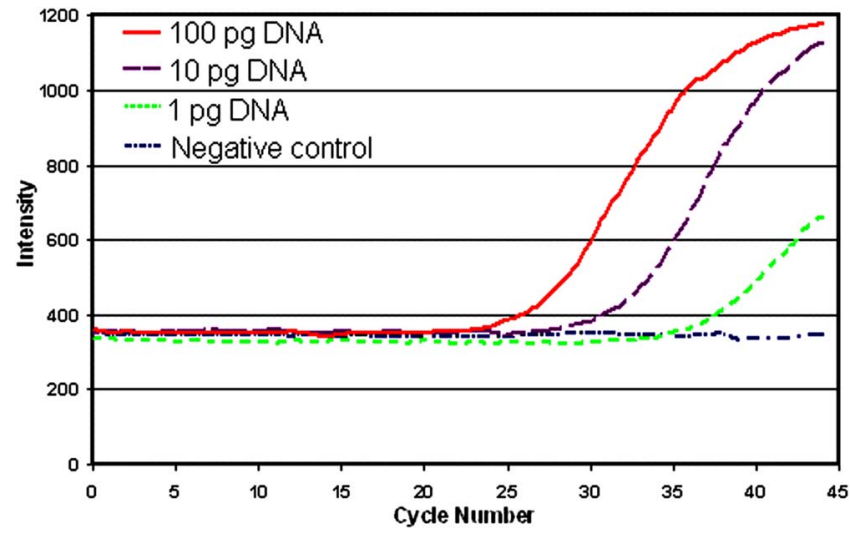

FIG. 14. (Color online) Real-time amplification of 600 bp B. cereus amplicon. Emission at $520 \mathrm{~nm}$ was counted using $300 \mathrm{~ms}$ integration time at $75^{\circ} \mathrm{C}$.

tained from higher rate of cooling are also shown in Fig. 12 for comparison. This process, however, increases the cooling time from around 2.3 to around $4.0 \mathrm{~s}$.

The elongation process starts when the temperature is around $60{ }^{\circ} \mathrm{C}$ and occurs over a wide temperature range. Therefore, this temperature stage is not as significant as the other PCR stage temperatures. Also, typically in a PCR cycle, there will be temperature holds of a few seconds during the elongation stage, which helps in making the samples to reach the required equilibrium temperature.

\section{B. PCR results}

Ultimately the efficacy of the VT-PCR is based upon its ability to support PCR. Throughout its development, the device has performed over 200 successful reactions. The DNA sources used to date include human, bacteria, viral, and plasmid DNAs. Some of these results are included in this section to demonstrate the capabilities of the VT-PCR.

\section{600 bp Bacillus cereus}

In Fig. 13 the results of agarose gel electrophoresis for 1 pg DNA (lanes 4 and 5), 10 pg DNA (lanes 6 and 7), and 100 pg DNA (lanes 8 and 9) are shown. The VT-PCR was programed for 45 cycles of $0 \mathrm{~s}$ at $92{ }^{\circ} \mathrm{C}, 1 \mathrm{~s}$ at $58{ }^{\circ} \mathrm{C}$, and $3 \mathrm{~s}$ at $72{ }^{\circ} \mathrm{C} .8 \mu \mathrm{l}$ of each sample was analyzed on a $1.8 \%$ agarose gel. There is a dramatic increase in the yield when the DNA concentration increases from $1 \mathrm{pg}$ DNA to $10 \mathrm{pg}$ DNA. The results of the fluorescence of SYBR Green are shown in Fig. 14 for 1 pg DNA (dotted line in green), 10 pg

TABLE I. PCR results for the vortex tube thermocycler.

\begin{tabular}{|c|c|c|c|}
\hline DNA Source & Size (bp) & PCR protocol & Time \\
\hline \multicolumn{4}{|c|}{ Human } \\
\hline DPD & 198 & {$\left[30 \mathrm{~s} 94^{\circ} \mathrm{C}\right] \times 1+\left[0 \mathrm{~s} 94^{\circ} \mathrm{C}, 0 \mathrm{~s} 60^{\circ} \mathrm{C}\right] \times 40$} & $11: 39$ \\
\hline GSTM-1 & 215 & {$\left[30 \mathrm{~s} 94{ }^{\circ} \mathrm{C}\right] \times 1+\left[0 \mathrm{~s} 94^{\circ} \mathrm{C}, 0 \mathrm{~s} 56^{\circ} \mathrm{C}\right] \times 35$} & $12: 20$ \\
\hline HBV18 & 145 & {$\left[120 \mathrm{~s} 95^{\circ} \mathrm{C}\right] \times 1+\left[2 \mathrm{~s} 95^{\circ} \mathrm{C}, 12 \mathrm{~s} 56^{\circ} \mathrm{C}\right] \times 50$} & 29:00 \\
\hline \multicolumn{4}{|c|}{ Bacterial } \\
\hline \multirow[t]{3}{*}{ E. coli $\mathrm{B}$} & 112 & {$\left[30 \mathrm{~s} 92^{\circ} \mathrm{C}\right] \times 1+\left[0 \mathrm{~s} 92{ }^{\circ} \mathrm{C}, 0 \mathrm{~s} 58^{\circ} \mathrm{C}\right] \times 35$} & 6:08 \\
\hline & 366 & $\begin{array}{l}{\left[30 \mathrm{~s} 92{ }^{\circ} \mathrm{C}\right] \times 1+\left[0 \mathrm{~s} 92{ }^{\circ} \mathrm{C}, 0 \mathrm{~s} 63^{\circ} \mathrm{C}, 2.5 \mathrm{~s} 72{ }^{\circ} \mathrm{C}\right]} \\
\times 35\end{array}$ & $7: 14$ \\
\hline & 392 & $\begin{array}{l}{\left[30 \mathrm{~s} 92{ }^{\circ} \mathrm{C}\right] \times 1+\left[0 \mathrm{~s} 92^{\circ} \mathrm{C}, 0 \mathrm{~s} 57^{\circ} \mathrm{C}, 4 \mathrm{~s} 72^{\circ} \mathrm{C}\right]} \\
\times 35\end{array}$ & $10: 15$ \\
\hline E. coli uidA & 186 & {$\left[30 \mathrm{~s} 90{ }^{\circ} \mathrm{C}\right] \times 1+\left[0 \mathrm{~s} 90^{\circ} \mathrm{C}, 0 \mathrm{~s} 56^{\circ} \mathrm{C}\right] \times 35$} & $6: 40$ \\
\hline $\mathrm{BC} 4$ & 600 & {$\left[30 \mathrm{~s} 92^{\circ} \mathrm{C}\right] \times 1+\left[0 \mathrm{~s} 92^{\circ} \mathrm{C}, 0 \mathrm{~s} 58^{\circ} \mathrm{C}\right] \times 35$} & $13: 13$ \\
\hline \multicolumn{4}{|c|}{ Viral } \\
\hline \multirow[t]{7}{*}{$\lambda$-DNA } & 96 & {$\left[30 \mathrm{~s} 90{ }^{\circ} \mathrm{C}\right] \times 1+\left[0 \mathrm{~s} 90^{\circ} \mathrm{C}, 0 \mathrm{~s} 58^{\circ} \mathrm{C}\right] \times 35$} & $7: 17$ \\
\hline & 341 & {$\left[30 \mathrm{~s} 94{ }^{\circ} \mathrm{C}\right] \times 1+\left[0 \mathrm{~s} 94^{\circ} \mathrm{C}, 0 \mathrm{~s} 62^{\circ} \mathrm{C}\right] \times 35$} & $7: 42$ \\
\hline & 800 & {$\left[30 \mathrm{~s} 93{ }^{\circ} \mathrm{C}\right] \times 1+\left[0 \mathrm{~s} 93^{\circ} \mathrm{C}, 2 \mathrm{~s} 60^{\circ} \mathrm{C}\right] \times 35$} & $10: 49$ \\
\hline & 1400 & {$\left[30 \mathrm{~s} 93{ }^{\circ} \mathrm{C}\right] \times 1+\left[0 \mathrm{~s} 93^{\circ} \mathrm{C}, 2 \mathrm{~s} 60^{\circ} \mathrm{C}\right] \times 35$} & $10: 49$ \\
\hline & 1953 & $\begin{array}{l}{\left[30 \mathrm{~s} 94^{\circ} \mathrm{C}\right] \times 1+\left[1 \mathrm{~s} 94^{\circ} \mathrm{C}, 1 \mathrm{~s} 60^{\circ} \mathrm{C}, 8 \mathrm{~s} 68^{\circ} \mathrm{C}\right]} \\
\times 35\end{array}$ & 18:05 \\
\hline & 2755 & $\begin{array}{l}{\left[30 \mathrm{~s} 91^{\circ} \mathrm{C}\right] \times 1+\left[1 \mathrm{~s} 91^{\circ} \mathrm{C}, 1 \mathrm{~s} 58^{\circ} \mathrm{C}, 11 \mathrm{~s} 72{ }^{\circ} \mathrm{C}\right]} \\
\times 35\end{array}$ & $19: 55$ \\
\hline & 7800 & $\begin{array}{l}{\left[30 \mathrm{~s} 92{ }^{\circ} \mathrm{C}\right] \times 1+\left[1 \mathrm{~s} 92{ }^{\circ} \mathrm{C}, 1 \mathrm{~s} 64{ }^{\circ} \mathrm{C}, 30 \mathrm{~s} 72{ }^{\circ} \mathrm{C}\right]} \\
\times 35\end{array}$ & 26:02 \\
\hline \multicolumn{4}{|c|}{ Plasmid } \\
\hline \multirow[t]{3}{*}{ pBr322 DNA } & 352 & $\begin{array}{l}{\left[30 \mathrm{~s} 93{ }^{\circ} \mathrm{C}\right] \times 1+\left[0.5 \mathrm{~s} 93{ }^{\circ} \mathrm{C}, 0.5 \mathrm{~s} 58{ }^{\circ} \mathrm{C}, 2 \mathrm{~s} 72{ }^{\circ} \mathrm{C}\right]} \\
\times 35\end{array}$ & 12:01 \\
\hline & 651 & $\begin{array}{l}{\left[30 \mathrm{~s} 93{ }^{\circ} \mathrm{C}\right] \times 1+\left[0.5 \mathrm{~s} 93{ }^{\circ} \mathrm{C}, 0.5 \mathrm{~s} 58{ }^{\circ} \mathrm{C}, 2 \mathrm{~s} 72{ }^{\circ} \mathrm{C}\right]} \\
\times 35\end{array}$ & 12:01 \\
\hline & 929 & $\begin{array}{l}{\left[30 \mathrm{~s} 93{ }^{\circ} \mathrm{C}\right] \times 1+\left[0.5 \mathrm{~s} 93{ }^{\circ} \mathrm{C}, 0.5 \mathrm{~s} 58{ }^{\circ} \mathrm{C}, 2 \mathrm{~s} 72{ }^{\circ} \mathrm{C}\right]} \\
\times 35\end{array}$ & 12:01 \\
\hline Amp-R DNA & 1000 & $\begin{array}{l}{\left[30 \mathrm{~s} 93{ }^{\circ} \mathrm{C}\right] \times 1+\left[0.5 \mathrm{~s} 93{ }^{\circ} \mathrm{C}, 0.5 \mathrm{~s} 61{ }^{\circ} \mathrm{C}, 2 \mathrm{~s} 72{ }^{\circ} \mathrm{C}\right]} \\
\times 35\end{array}$ & $11: 45$ \\
\hline
\end{tabular}


DNA (dashed line in purple), and $100 \mathrm{pg}$ DNA (solid line in red). The signals were clearly distinguishable from background at 26 cycles (solid line in red), 31 cycles (purple), and 38 cycles (dotted line green). The average cycle time was $18 \mathrm{~s}$, because a total elongation time per cycle of $3 \mathrm{~s}$ was used, which still corresponds to 9 min for 30 cycles. Real-time optical detection of the amplified PCR products (Fig. 14) displays results that correspond to the successfully amplified DNA fragments that were analyzed by gel electrophoresis (Fig. 13).

\section{Other PCR experiments}

Some of the hundreds of successful reactions performed by the VT-PCR are shown in Table I. Within each category of the DNA sources, several amplicons of sizes ranging from 96 to 7800 bp were successfully PCR amplified. The times typically increase with amplicon size since larger amplicons can require longer holds at the denaturation, annealing, and, most notably, the elongation temperatures. A single exception to this trend is evident from the HBV18 amplification. Its protocol is taken directly from a kit designed around a specific optical detection/dye system associated with it. Regardless, the VT-PCR is a fully functional PCR machine capable of amplifying specific DNA target sequences in less time than conventional PCR devices. The last number in the third column is the total number of cycles and the data in the last column can be used to calculate an equivalent time for 30 cycles.

The effectiveness of a PCR machine may be described in terms of overall efficiency $(Y)$, where $X=(1+Y)^{N}$ is the DNA amplification yield and $N$ is the number of cycles. Typical PCR amplification has an overall efficiency of 70\%-80\% and requires approximately 35 cycles for 108 -fold amplification. An overall efficiency of $75 \%$ is typical for the results shown in Table I, although higher efficiencies have been recorded.

\section{SUMMARY}

The VT-PCR is a compact device, which effectively and rapidly cycles six DNA samples through 30 cycles of PCR stages without any temperature holds, in less than $6 \mathrm{~min}$.

During the denaturation stage, the temperature difference between the samples has been quite small (maximum variation around $\pm 0.5^{\circ} \mathrm{C}$ ). The maximum temperature difference within each sample has been around $1.6{ }^{\circ} \mathrm{C}$, when the denaturation stage temperature is $95^{\circ} \mathrm{C}$. When temperature holds are adopted, the thermal performance improves even further, as all the capillaries attain the required equilibrium temperature during the hold period. The study of the temperature distribution within a sample indicates that the thermocouple should be positioned around the center of the sample capillary, in order to attain the set desired temperature over a larger cross-sectional area of the sample capillary.

By reducing the heat transfer rate at some stage of the cooling process, the temperature distribution between and within the samples becomes almost uniform (maximum variation around $1{ }^{\circ} \mathrm{C}$ ) during the annealing stage.
It is shown that the VT-PCR is a fully functional PCR machine capable of amplifying specific DNA target sequences in less time than conventional PCR devices.

\section{ACKNOWLEDGMENTS}

Financial support for this study from the NIH (R21RR20219) and ARL (W911NF-04-2-0011) is gratefully acknowledged.

\section{NOMENCLATURE}

$C_{1 \varepsilon}, C_{2 \varepsilon}, C_{\mu}=$ constants

$G_{k}=$ generation of turbulent kinetic energy

$C_{p}=$ specific heat at constant pressure $(\mathrm{J} / \mathrm{kg} \mathrm{K})$

$k=$ turbulent kinetic energy $\left(\mathrm{m}^{2} / \mathrm{s}^{2}\right)$

$n=$ time step

$p=$ pressure $\left(\mathrm{N} / \mathrm{m}^{2}\right)$

$q=$ heat transfer rate $(\mathrm{J} / \mathrm{s})$

$\operatorname{Re}=$ Reynolds number

$S_{\varepsilon}=$ source term in the equation for $\varepsilon$

$S_{k}=$ source term in the equation for $k$

$T=$ temperature $\left({ }^{\circ} \mathrm{C}\right)$

$t=$ time $(\mathrm{s})$

$u, v=$ velocity components in $x$ and $y$ directions $(\mathrm{m} / \mathrm{s})$

$x, y=$ Cartesian coordinates $(\mathrm{m})$

\section{Greek symbols}

$\varepsilon=$ rate of dissipation

$\lambda=$ thermal conductivity $(\mathrm{W} / \mathrm{m} \mathrm{K})$

$\rho=$ density $\left(\mathrm{kg} / \mathrm{m}^{3}\right)$

$\mu=$ coefficient of viscosity $\left(\mathrm{N} \mathrm{s} / \mathrm{m}^{2}\right)$

$\sigma_{k}=$ turbulent Prandtl number in the equation for $k$

$\sigma_{\varepsilon}=$ turbulent Prandtl number in the equation for

Subscripts

$i, j=$ tensor notations

$t=$ turbulent quantity

$\infty=$ freestream conditions

\section{Superscripts}

$'$ = fluctuating quantities

$"$ = pressure or velocity correction

${ }^{*}=$ guess pressure or velocity

${ }^{1}$ R. Saiki, S. Scharf, F. Faloona, K. B. Mullis, G. T. Horn, H. A. Erlich, and N. Arnheim, Science 230, 1350 (1985).

${ }^{2}$ S. Kogan, M. Doherty, and J. Gitschier, N. Engl. J. Med. 317, 985 (1987).

${ }^{3} \mathrm{H}$. Erlich, PCR Technology: Principles and Applications for DNA Amplification (Stockton, New York, 1989).

${ }^{4}$ R. Saiki, P. S. Walsh, C. H. Levenson, and A. H. Erlich, Proc. Natl. Acad. Sci. U.S.A. 86, 6230 (1989).

${ }^{5}$ D. Persing, F. C. Tenover, J. Versalovic, Y.-W. Tang, E. R. Unger, D. A. Relman, and T. J. White, Diagnostic Molecular Biology: Principles and Applications (ASM, Washington, DC, 1993).

${ }^{6} \mathrm{~K}$. Mullis, F. Ferré, and R. Gibbs, The Polymerase Chain Reaction (Birkhauser, Boston, 1994).

${ }^{7}$ S. Nicoll, A. Brass, and H. Cubie, J. Virol. Methods 96, 25 (2001).

${ }^{8}$ R. Saiki, in PCR Technology: Principles and Applications for DNA Amplification, edited by H. Erlich (Ref. 3).

${ }^{9}$ R. Higuchi, G. Dollinger, S. Walsh, and R. Griffith, Biotechnology 10, 413 (1992).

${ }^{10}$ N. Svanvik, W. Westman, and M. Kubista, Anal. Biochem. 282, 26 (2000). 
${ }^{11}$ I. Nazarenko, P. Rick, L. Brian, O. Mohamad, and R. Ayoub, Nucleic Acids Res. 30, 2089 (2002)

${ }^{12} \mathrm{~B}$. Johnson, The competition heats up: The annual review of thermal cyclers takes a sneak peak at the new products for 1999, The Scientist, Vol. 12, p. 24.

${ }^{13}$ C. Wittwer, G. Filmore, and D. Hillyard, Nucleic Acids Res. 17, 4353 (1989).

${ }^{14}$ C. Wittwer, G. Filmore, and D. Garling, Anal. Biochem. 186, 328 (1990).

${ }^{15}$ C. Wittwer and D. Garling, BioTechniques 10, 76 (1991).

${ }^{16} \mathrm{C}$. Wittwer, G. Reed, and K. Ririe, in The Polymerase Chain Reaction, edited by K. Mullis, F. Ferré, and R. Gibbs (Ref. 6).

${ }^{17}$ A. Quintanar and R. Nelson, U.S. Patent No. 6,472,186 (29 October
2002).

${ }^{18}$ S. Whitney, Ph.D. thesis, University of Nebraska-Lincoln, 2004.

${ }^{19}$ R. Ebmeier, S. Whitney, A. Sarkar, M. Nelson, N. V. Padhye, G. Gogos, and J. V. Hendrik, Rev. Sci. Instrum. 75, 5356 (2004).

${ }^{20}$ R. Ebmeier, M.S. thesis, University of Nebraska-Lincoln, 2004.

${ }^{21}$ G. Ranque, J. Phys. Radium 4, 112 (1933).

${ }^{22}$ R. Hilsch, Rev. Sci. Instrum. 18, 108 (1947).

${ }^{23}$ S. V. Patankar, Numerical Heat Transfer and Fluid Flow (Hemisphere, New York, 1980).

${ }^{24}$ B. E. Launder and D. B. Spalding, Lectures in Mathematical Models of Turbulence (Academic, London, 1972). 